\title{
PEER INFLUENCE AS DETERMINANTS OF UNIVERSITY- COMMUNITY PREFERENCE FOR GSM SERVICE PROVIDERS IN ONDO STATE, NIGERIA
}

\author{
Olowe, Modupe Oluwatoyin \\ Department of Business Education, Bamidele Olumilua University of Education, Science and \\ Technology, Ikere- Ekiti, Ekiti State, Nigeria.
}

Article DOI: https://doi.org/10.36713/epra6648

DOI No: 10.36713/epra6648

\begin{abstract}
The study investigated the strength of peer influence as determinants of university-community preference for GSM service providers in Ondo State, Nigeria. Two research questions were raised to guide the study. The study adopted a descriptive research survey. The population for this study consisted of the undergraduate students, academics staff and non-teaching staff of universities in Ondo State who were subscribers to each of the various popular service providers in Ondo State, Nigeria, namely, MTN, Globacom (Glo), Airtel and Etisalat (now 9mobile). The four universities have 34,246 students, 1,642 academic staff and 2,743 non-teaching staff totaling 38,631. Random sampling technique was used to select the sample of three thousand, and eight hundred and sixty-five $(3,865)$ respondents. Questionnaire was used for data collection; the reliability was done by using Gultman Split-half method with a r-value of 0.859 . Completed copies of the questionnaire were retrieved from the respondents, 3,863 copies of the instrument were distributed 3,671 copies were collected and used for analysis. The data generated was analyzed using descriptive statistics, charts, mean, standard deviation and percentage. The findings of the study revealed that majority of the respondents are students and friends pressurized themselves to use the network they have been using, it was recommended that, the students should be careful not to be influenced by friends to choose a wrong network provider that might affect them in their academics.
\end{abstract}

KEY WORDS: Peer Influence, Network Providers and University-Community

\section{INTRODUCTION}

Global System for Mobile Communications (GSM) has grown so rapidly in Nigeria,it has been rightly described as one of the fastest growing in communication business markets and this has triggered the existence of many service providers. The popular network providers in Nigeria are MTN, Globacom (Glo), Airtel and Etisalat now 9mobile. These service providers compete for customers' loyalty that is customer's preference. The word 'preference' is a strong liking for something more than another. It is the power and opportunity of choosing. According to Cambridge Academic dictionary (2022) is liking or wanting one thing more than another. Wikipedia (2022) stated that preference is a technical term usually used in relation to choosing between alternatives, for example someone prefers A over B if they would rather choose A than B. 


\section{SJIF Impact Factor 2021: 8.013| ISI I.F.Value:1.241| Journal DOI: 10.36713/epra2016 ISSN: 2455-7838(Online) EPRA International Journal of Research and Development (IJRD)

Peers are people who are part of the same social group, so the term "peer pressure" refers to the influence that peers can have on each other, the term "pressure" implies that the process influences people to do things that they may be resistant to, or might not otherwise choose to do. Peer influence can be a powerful force as every individual wants a sense of belonging to a group. Peer group vary in their norms and values and some people find themselves under peer pressure to behave in socially desirable ways. (Omonike, Olagundoye, Morakinyo \& Benjamin, 2015).

Maria (2014) expressed that peers with similar interests, similar academic standing who enjoy doing the same thing tend to gravitate towards each other. Whether it is gender, age, socioeconomic status, ethnicity or interest, they tend to gravitate towards those that are more similar to them. The relationship of choice to peer influence is, the group or social class of an individual will influence what the person needs or wants. The individual will like to live to the standard of those he is associating with. A group of people of approximately the same age who have similar interests, background or social status. The members of this group are likely to influence an individual's beliefs and behaviours (Natalie, Katerna \& Elizabeth, 2019).

\section{STATEMENT OF THE PROBLEM}

The network providers are competing for customers and the retention of the new and old customers, it was observed by the researcher that many customers do switch from one service provider to the other frequently, some operates with two or three of the network providers and some customers stay put with one service provider for reasons best known to them. The customers still have preferences for the service providers of their choice. Factors that discriminate the preferences customers have for one service provider over others are not precisely known. In the light of the above, this study examined the extent to which peer influence were determinant of university- community preferences for GSM service providers.

\section{OBJECTIVES OF THE STUDY}

The broad objective for the study was to examine peer influence as determinant of university community preference for GSM service providers. Specifically, the study

1. Determine the categories of the respondent in the study.
2. Determined the Strength of peer influence as determinants of university-community preference for GSM service provider.

\section{RESEARCH QUESTION}

1. What are the categories of the respondents?

2. What is the strength of peer influence as determinant of university-community preference for GSM service provider?

\section{SIGNIFICANCE OF THE STUDY}

The outcome of the study will be of immense benefit to the students to know and to take decision on which network to use, the results will also help the staff (academics and non-teaching) to know which network to cling with. Also the outcome of the study will be of immense benefit to the service providers and it will assist them to make decisions such as what features to design, prices to offer to customers and how much to spend on advertisement and promotions to retain their customers.

\section{SCOPE OF THE STUDY}

The study focused on peer influence as discriminants of university-community preference for GSM service providers. The study was restricted to Federal and State Universities which are located in the three Senatorial Zones in Ondo State. The respondents for this study consisted of students and staff (academic and nonteaching) using the four popular service providers, MTN, Globacom (GLO), Airtel and 9mobile.

\section{LITERATURE REVIEW}

This section focused on the review of related literature both theoretically and empirically.

\section{Theoretical Framework}

The study is built on Choice Theory, which was developed by psychiatrist William Glasser (1998). The theory states that we are motivated by a never ending quest to satisfy our five basic needs woven into our genes. The theory contends that we are internally motivated not externally motivated by rewards and punishment. Choice Theory suggests that we always have some capacity to make choices and exercise control in our lives. The theory teaches that we are always motivated by what we want at that moment.

\section{Conceptual Review Concept of Peer Influence}

Peer group are people of similar interests, age, background or social status. Age group are likely to 


\section{SJIF Impact Factor 2021: 8.013| ISI I.F.Value:1.241| Journal DOI: 10.36713/epra2016 ISSN: 2455-7838(Online) EPRA International Journal of Research and Development (IJRD)}

influence the person's beliefs and behavior. It contains hierarchies and distinct patterns of behavior. (Macionis, 2010).

The concept of peer influence focuses on the relationship between the adopter and his/her social environment. When individuals are together in groups, they exercise influence on each other. There are two competing perspectives on how peer influence affects an individual's behavior. An individual might agree with another individual's opinion because he or she was persuaded by the arguments (informational influence) or because he or she concedes to some kind of social pressure (normative influence). Peer influence as a concept is discussed in a variety of disciplines including sociology, psychology. Peer influence is commonly defined as the extent to which peers exert influence on the attitudes, thoughts, and actions of an individual.

Peers influences include the spread opinions of friends, family, colleagues and reference group. Mostly individuals will be influenced and get into following their trend and take their opinions as a standard of their purchase decisions. Peers can influence each other either in a positive way or negative way (Steinberg, 2010).

Elizabeth (2014) stated that Peers are people who are part of the same social group, so the term "peer pressure" refers to the influence that peers can have on each other. Although peer pressure does not necessarily have to be negative, the term "pressure" implies that the process influences people to do things that may be resistant to, or might not otherwise choose to do. According to Uzezi (2017) stated that many peer groups can exert a positive influence on their friend.

\section{Peer Influence and Choice}

Peer influence is commonly defined as the extent to which peers exert influence on the attitudes, thoughts, and actions of an individual. A strong peer influence was also found to impact the purchase of publicly consumed necessities than privately consumed necessities. Peer influence is influence on observers or an individual who get encouraged to follow others by changing their attitude, values or behavior to conform to those of the influencing group or individual. Peer conformity in young people is most pronounced with respect to style, taste, appearance, ideology, and values Peer pressure is commonly associated with episodes of adolescent risk taking because these activities commonly occur in the company of peers. Affiliation with friends who engage in risk behaviors has been shown to be a strong predictor of an adolescent's own behavior. Peer pressure can also have positive effects when youth are pressured by their peers toward positive behavior, such as volunteering for charity or excelling in academics. Peer influence can swing both the negative and the positive side, it has a deep impact on one's decision making ability when it comes to choosing (Sumit, 2011).

\section{Empirical Review}

The following are the empirical study on peer Influence Studies on Peer Influence

Jorn and Philipp (2007) conducted a study on peer influence in network markets: An Empirical Investigation, the researchers analyze the effect of peer influence on the diffusion of an innovative network good, it was arguing that the adopters of a network good have an incentive to convince others to purchase the same product because their utility depends on the number of other users. These peer-effect influences individuals' adoption decisions alongside the more familiar installed-base-effect based on the individual's own insight that a larger number of installed units increase his/her benefit of adopting.

Makgosa and Mohube (2007) carried out a study on peer influence on young adults' products purchase decisions. The study focuses on peer influence among young adults' products purchase decisions. A convenience sample of 101 university students participated in this study. The results of analysis of variance and t-tests indicated that there is more normative influence for a public luxury than for a private luxury, the results demonstrated that the influence of peers varies across various product categories.

\section{METHODOLOGY}

The study adopted a descriptive research survey. The population for this study consisted of the undergraduate students, academics staff and nonteaching staff of universities in Ondo State who were subscribers to each of the various popular service providers in Ondo State, Nigeria. The popular network providers in Nigeria are: MTN, Globacom (Glo), Airtel and Etisalat (now 9mobile). The four universities have 34,246 students, 1,642 academic staff and 2,743 nonteaching staff totaling 38,631. Random sampling technique was used to select the sample, the sample for this study are three thousand, and eight hundred and sixty-five $(3,865)$ respondents, i.e. 10 per cent of the population. A questionnaire was used for data collection. The reliability was done by administering the instrument in University of Nsukka, Ikere Campus, 


\section{SJIF Impact Factor 2021: 8.013| ISI I.F.Value:1.241| Journal DOI: 10.36713/epra2016 ISSN: 2455-7838(Online) EPRA International Journal of Research and Development (IJRD)

Ekiti State, the data collected was analysed using Gultman Split-half method and a r-value of 0.859 was obtained indicating that the instrument is reliable for the study. The researcher and two trained research assistants administered the instrument, the instrument was given personally to the network subscribers in the study area. The researcher and the trained research assistant attended to all questions and gave instructions to the respondents. The administration of the instrument took four months. After filling the instrument, completed copies of the questionnaire were retrieved from the respondents, 3,863 copies of the instrument were distributed, only 3,671 copies were found to be properly filled and used for analysis. The data generated for research questions was analyzed using descriptive statistics charts, mean, standard deviation and percentage.

\section{RESULTS AND DISCUSSIONS}

Data were collected on the major variables of the study. 3865 copies of the instruments were distributed, only 3671 copies were found to be properly filled and used for analysis.

Research Question 1: What are the categories of the respondents?

Table 1: Categories of the Respondents

\begin{tabular}{lll}
\hline Variables & Frequency & Percentages \\
\hline Students & 3231 & $88 \%$ \\
Academic Staff & 165 & $5 \%$ \\
Non-Teaching Staff & 275 & $7 \%$ \\
\hline
\end{tabular}

The results in Table 1 revealed the categories of the respondents sampled for the study. It was found that majority of the respondents are students with 3,231 $(88 \%)$, this was followed by academic staff $165(5 \%)$ and non-teaching staff with $275(7 \%)$ of the population of the study. This is an indication that all sections/ categories of people in the institutions where represented in the study to give viable responses.

The result in Table 1 is further presented in Figure 1.

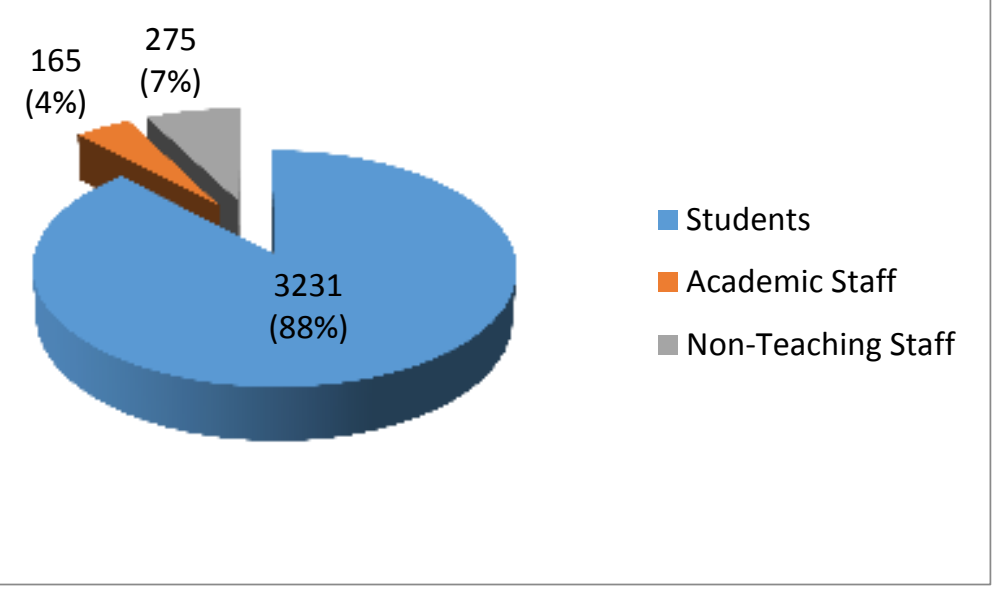

Figure 1: Pie Chart Showing the Status of the Respondents

Research Question 2: What is the strength of peer influence as discriminants of university-community preference for GSM service provider? 


\section{SJIF Impact Factor 2021: 8.013| ISI I.F.Value:1.241| Journal DOI: 10.36713/epra2016 ISSN: 2455-7838(Online) EPRA International Journal of Research and Development (IJRD)}

Table 2: Strength of Peer Influence as Discriminants of University Community Preference for GSM Service Provider

\begin{tabular}{|c|c|c|c|c|}
\hline $\mathbf{S} / \mathbf{N}$ & Items & Mean & St. D & Decision \\
\hline 1. & I pressurize friends to use the network I have been using & 3.24 & 0.87 & Agreed \\
\hline 2. & I tease someone to like the network I am using. & 3.33 & 0.79 & Agreed \\
\hline 3. & I have been pressured into subscribing into friends' network & 2.79 & 0.54 & Agreed \\
\hline 4. & $\begin{array}{l}\text { I pretend to my friends to like a network just because they will make fun of me } \\
\text { when they discover I don't like the network. }\end{array}$ & 1.63 & 0.35 & Disagreed \\
\hline 5. & I pretend to like a network because my friends told me to do so. & 1.72 & 0.32 & Disagreed \\
\hline 6. & I was forced by my friends to change to their network. & 3.25 & 0.76 & Agreed \\
\hline 7. & I know others that are influenced by their friends. & 3.38 & 0.79 & Agreed \\
\hline 8 & As an individual, I am influenced by peer pressure. & 3.34 & 0.89 & Agreed \\
\hline 9. & I am influenced by peer pressure on the network to be used. & 3.76 & 0.96 & Agreed \\
\hline 10. & $\begin{array}{l}\text { I am influenced by peer pressure on the network to be used and it makes me } \\
\text { feel bad. }\end{array}$ & 1.88 & 0.32 & Disagreed \\
\hline 11. & Giving in to peer pressure makes one to be less confident. & 1.79 & 0.36 & Disagreed \\
\hline 12. & Peer pressure on network use affect teenagers. & 3.76 & 0.87 & Agreed \\
\hline 13. & $\begin{array}{l}\text { Giving into peer pressure on the network to be used makes me to be successful } \\
\text { in my work/studies. }\end{array}$ & 3.11 & 0.80 & Agreed \\
\hline 14. & $\begin{array}{l}\text { I would have made a best choice of network if I was not pressurized into the } \\
\text { one I am using presently. }\end{array}$ & 2.32 & 0.56 & Disagreed \\
\hline 15. & $\begin{array}{l}\text { Peer influence is more prevalent in youth in all levels concerning the network } \\
\text { to use. }\end{array}$ & 3.54 & 0.96 & Agreed \\
\hline 16. & Peer pressure is good in choosing a network to be used. & 3.28 & 0.86 & Agreed \\
\hline 17. & $\begin{array}{l}\text { Most of my friends are using the same GSM network; this shows the } \\
\text { seriousness of peer pressure. }\end{array}$ & 3.33 & 0.79 & Agreed \\
\hline 18. & Peer pressure only affects people at their adolescent years. & 1.57 & 0.44 & Disagreed \\
\hline 19. & I have been pressured into switching to the network I don't like. & 1.65 & 0.34 & Disagreed \\
\hline 20. & $\begin{array}{l}\text { There are situations in which I stand out that I will not agree in using the } \\
\text { network pressurized by my friends to use. }\end{array}$ & 3.36 & 0.87 & Agreed \\
\hline 21. & $\begin{array}{l}\text { Peer pressure affects me at this age on the network to use. } \\
\text { Grand Value }\end{array}$ & $\begin{array}{l}3.78 \\
2.85\end{array}$ & $\begin{array}{l}0.88 \\
0.66\end{array}$ & $\begin{array}{l}\text { Agreed } \\
\text { Agreed }\end{array}$ \\
\hline
\end{tabular}

The result of analysis presented in Table 2 showed the strength of peer influence as discriminants of university-community preference for GSM service provider. The grand mean value (2.85) of respondents on peer influence was greater than the decision level of 2.50. This indicated that peer influence as discriminants of university-community preference for GSM service provider. Many of the respondents agreed that they pressurized friends and friend pressurized them to use the network they have been using. The respondents said they equally know others that were influenced by their friends to subscribe and use the same network with their friends. The decision to use the same network service with friends has never led to regret by the customers, hence making them to have confident in the network service provider. The influence of peers in the use of network has also contributed to students' academic success. These responses indicated that peer influence is another factor that determined the choice of university-community preference for GSM service provider.

\section{DISCUSSION OF FINDINGS}

The findings of the study revealed that majority of the respondents are students followed by academic staff and non-teaching staff.

The study also revealed that they pressurized friends and friend pressurized them to use the network they have been using, this was supported by Macionis (2010), peer group are people of similar interests, age, background or social status. Age groups are likely to influence the person's beliefs and behavior. The decision to use the same network service with friends has never led to regret by the customers, hence making 


\section{SJIF Impact Factor 2021: 8.013| ISI I.F.Value:1.241| Journal DOI: 10.36713/epra2016 ISSN: 2455-7838(Online) EPRA International Journal of Research and Development (IJRD)}

them to have confidence in the network service provider. The influence of peers in the use of network has also contributed to students' academic success. Steinberg (2010) pointed it out that peers can influence each other either in a positive way or negative way, but in this study, they influence themselves positively.

\section{CONCLUSION}

The study identified that the ages between 21 to 30 formed the majority of people in the university that are using different mobile network. The study submits that the peer influences themselves in the area of choosing network providers. The study will help the network providers to improve more in the area they are slacking and plan an effective strategy to get more subscribers.

\section{RECOMMENDATIONS}

The following recommendations were made in the study.

1. The students should be careful not to be influenced by friends to choose a wrong network provider because it might affect them in getting information on net at the appropriate time which may hinder their academics.

2. The academics and non-teaching staff should be careful not to be influenced by friends and colleagues to choose a wrong network provider because it might affect them in area of socializing, getting information on net at the appropriate time depending on office they are holding and also it can hinder the academics of those that engaged in educational programmes.

3. The network providers, Etisalat (9-mobile), Airtel and GLO should organized public talk/seminar to the public to find out their weakness and strength, this will enable them to improve in the services rendered.

4. The GSM service provider should do training and retraining for their staff, this would be of benefit to their subscribers.

\section{REFERENCES}

1. Cambridge Business English Dictionary(2022). Preference. Cambridge University Press Retrieved from https://dictionary.cambridge.org. 2022.

2. Elizabeth, H. (2014). What is peer pressure? The American heritage ${ }^{\circledR}$ Stedman's Medical Dictionary Copyright $($ C 2002, 2001, 1995 by Houghton Mifflin Company. Published by Houghton Mifflin Company.
3. Jorn, H. B., \& Philipp. K. (2007). Peer influence in network markets: An empirical investigation. American Journal of Sociology 106, 1409-1435.

4. Makgosa, R., \&Mohube, K. (2007). Peer influence on young adults' products purchase decisions. African Journal of Business Management. 064-071, Available online http://www.academicjournals.org/ajbm ISSN 19938233 @2007 Academic Journals.

5. Maria, R. T. (2014). Friendships, peer influence, and peer pressure during the teen years. Retrieved from www.peer Influence, on August, 2015.

6. Macionis, G., \& John, L. (2010). Sociology, $7^{\text {th }}$ Canadian Ed Toronto Canada Inc. Retrieved from www.wikipedia.org.com. October 2017.

7. Natalie, S., Katerina, S. \& Al-jbour, E. (2019). Peer Groups, department of child and youth studies, Brock University, St Catharines, ON, Canada. DOI 101007/978-3-319-16999-6 155-1

8. Omonike O., Olagundoye, H., Morakinyo, B., \& Benjamin, O. (2015). Perception of undergraduate students on peer pressure, environment, Gender and self-esteem towards virginity. Research on Humanities and Social Sciences. 5(22), 93-96.

9. Pam, L. (2009). Peer influence, Retrieved from Community action network, education. Com. on July, 2015.

10. Steinberg, L. (2010). Adolescence. New York: McGraw, Hill. Retrieved on October 2017 from www.wikipedia.org.com.

11. Smit, B. (2011). Peer Pressure May Lead to Wrong Choices. Retrieved from http://www.thehindu.com.article

12. Uzezi, J.G. (2017). Relationship between Peer group influence and student academic in Chemistry at secondary school level. Retrieved from http://article.scieducational research.com. 1

13. Wikipedia (2021). Preference. Retrieved from www.wikipedia.com, 2021 